\title{
Risk factors of cardiac allograft vasculopathy
}

\author{
Bożena Szyguła-Jurkiewicz ${ }^{1}$, Wioletta Szczurek ${ }^{2}$, Mariusz Gąsiorr ${ }^{1}$, Marian Zembala ${ }^{3}$ \\ $13^{\text {rd }}$ Department of Cardiology, SMDZ in Zabrze, Medical University of Silesia, Katowice, Poland \\ ${ }^{2}$ Student Research Club, $3^{\text {rd }}$ Department of Cardiology, SMDZ in Zabrze, Medical University of Silesia, \\ Katowice, Poland \\ ${ }^{3}$ Department of Cardiosurgery, Transplantology and Vascular Surgery, SMDZ in Zabrze, Medical University \\ of Silesia, Katowice, Poland
}

Kardiochirurgia i Torakochirurgia Polska 2015; 12 (4): 328-333

\begin{abstract}
Despite advances in prevention and treatment of heart transplant rejection, development of cardiac allograft vasculopathy (CAV) remains the leading factor limiting long-term survival of the graft. Cardiac allograft vasculopathy etiopathogenesis is not fully understood, but a significant role is attributed to endothelial cell damage, caused by immunological and nonimmunological mechanisms. Immunological factors include the differences between the recipient's and the donor's HLA systems, the presence of alloreactive antibodies and episodes of acute rejection. Among the non-immunological factors the most important are the age of the donor, ischemia-reperfusion injury and cytomegalovirus infection. The classical cardiovascular risk factors (diabetes, hypertension, obesity and hyperlipidemia) are also important. This study presents an up-to-date overview of current knowledge on the vasculopathy etiopathogenesis and the role played by endothelium and inflammatory processes in CAV, and it also investigates the factors which may serve as risk markers of cardiac allograft vasculopathy.

Key words: cardiac allograft vasculopathy, risk factors, endothelium.
\end{abstract}

\section{Introduction}

Cardiac allograft vasculopathy (CAV), also called accelerated coronary artery disease, is one of the major causes of late failure after heart transplantation and greatly reduces the graft survival in long-term observation, i.e. from 12 months after heart transplantation $[1,2]$. The frequency of CAV is estimated at $8 \%$ one year after transplantation, at $30 \%$ in a 5 -year follow-up, and as high as $50 \%$ within 10 years [2]. Although a relatively small percentage of patients develops vasculopathic changes within the first year, the quick and fulminant CAV development in this period does not bode well for graft survival [3].

\section{Streszczenie}

Pomimo postępów w zapobieganiu i leczeniu epizodów odrzucania, waskulopatia przeszczepionego serca (cardiac allograft vasculopathy - (AV) pozostaje nadal istotnym czynnikiem ograniczającym długoterminowe przeżycie graftu. Etiopatogeneza CAV nie została w pełni poznana, jednak kluczową rolę przypisuje się uszkodzeniu komórek śródbłonka naczyń wieńcowych z udziałem mechanizmów immunologicznych i nieimmunologicznych. Do czynników immunologicznych należą różnice pomiędzy układem HLA biorcy i dawcy, obecność alloreaktywnych przeciwciał oraz epizody ostrego odrzucania przeszczepu. Natomiast wśród czynników nieimmunologicznych istotne są: wiek dawcy, uszkodzenie niedokrwienno-reperfuzyjne oraz zakażenie wirusem cytomegalii. Nie bez znaczenia są również klasyczne czynniki ryzyka sercowo-naczyniowego (cukrzyca, nadciśnienie, otyłość i hiperlipidemia). W pracy przedstawiono przegląd dotychczasowej wiedzy na temat etiopatogenezy waskulopatii, roli śródbłonka i procesu zapalnego w jej powstawaniu, a także poddano analizie czynniki mogące służyć jako markery ryzyka rozwoju waskulopatii w przeszczepionym sercu.

Stowa kluczowe: waskulopatia przeszczepionego serca, czynniki ryzyka, śródbłonek.

Cardiac allograft vasculopathy manifests itself in a wide range of changes. Characteristic is the picture of vasculopathy, in which diffuse intima proliferative lesions of the distal segments of the coronary arteries, resulting from the endothelium damage, are predominant. The main cells involved in the cell proliferation are membrane smooth muscle cells, fibroblasts, macrophages and T cells [4, 5]. Coronary artery damage contributes to the development of CAV induced by various noxious stimuli. A significant role is attributed to immune system activation. Particularly important are the episodes of acute rejection and the presence of anti-HLA and other antibodies (non-HLA and alloreactive T cells),

Address for correspondence: Assoc. Prof. Bożena Szyguła-Jurkiewicz, $3^{\text {rd }}$ Department of Cardiology, SMDZ in Zabrze,

Medical University of Silesia, Katowice, 9 Curie-Skłodowskiej St., 41-800 Zabrze, Poland, phone: +48 60410299 , e-mail: centrala4@wp.pl 
which affect the progression rate in the vessels [4, 5]. Additionally, an important role in CAV development is assigned to non-immunological factors which include the donor's age and gender, cytomegalovirus (CMV) infections and ischemia-reperfusion injury $[6,7]$. An equally important role is played by the classic cardiovascular risk factors (obesity, dyslipidemia, hypertension, diabetes, and smoking) $[4,8]$. Vasculopathy development is also, paradoxically, associated with immunosuppressive therapy conducted after heart transplantation, due to the side effects of immunosuppressive drugs, including induction of post-transplant diabetes mellitus, hypertension, hyperlipidemia, nephrotoxicity and increased incidence of CMV infections $[4,9]$. These factors in turn influence the rate of CAV progression. Calcineurin inhibitors and glucocorticosteroids may have particularly adverse effects on vasculopathy development [9].

The understanding of the vasculopathy pathophysiology, as well as the role of endothelial dysfunction and inflammation in the CAV pathogenesis, plays a key role in the development of new therapies. The possibilities of interventional treatment of graft vasculopathy are limited. Thus, CAV prevention is the key to improvement of transplant patients' survival.

\section{Cardiac allograft vasculopathy etiopathogenesis and the role of the endothelium}

The endothelial cells constitute the inner lining of the lumen and are characterized by diverse biological activity. The substances produced within them play an important role in vascular tone regulation and the preservation of their proper functionality. A properly functioning endothelium prevents leukocyte adhesion and platelet aggregation, inhibits proliferation of vascular smooth muscle cells and regulates coagulation [10].

Cardiac allograft vasculopathy etiopathogenesis is complex and multifactorial. From the perspective of CAV pathophysiology, endothelial activation seems to be the starting point for the development of transplant vasculopathy [1]. Endothelial dysfunction is caused by both immunological and non-immunological risk factors. After cardiac transplant, the humoral and cellular immune response to HLA antigens, endothelial cell antigens and ischemic injury is the source of endothelial destruction [11, 12]. At the point of the vascular endothelial cell damage, it leads to procoagulant surface expression and, therefore, increased expression of adhesion molecules (endothelium leukocyte adhesion molecule 1 [ELAM-1], intercellular adhesion molecule 1 [ICAM-1], vascular cell adhesion molecule 1 [VCAM-1]), which, together with the chemoattractants, cause the migration of granulocytes, macrophages and lymphocytes to the site of the process $[10,13,14]$. Recruitment of leukocytes requires intercellular communication between infiltrating cells, the endothelium, parenchymal cells, and components of the extra-cellular matrix [13].

The exposed collagen fibers of the damaged endothelium are the site of increased aggregation and platelet adhe- sion [15]. They change their shape, adjacent to each other, and undergo aggregation to form a platelet thrombus. This leads to expression of the receptors for fibrinogen and its binding on the platelet surface, as well as the exposure of many membrane proteins $[14,16]$. Also characteristic for CAV development are the stimulation of vascular smooth muscle proliferation and vasoconstriction, increased microvascular permeability and increased production of reactive oxygen species [10]. Initiation of endothelial cell injury triggers a cascade of processes associated with the release of cytokines and the activation of inflammatory mediators which would consequently contribute to deepening of the vasculopathic changes [11-14]. The genetic and metabolic factors of the recipient and the donor acting at the level of the coronary artery walls are not without significance for the progression of CAV [17]. Mutations in hemostasis adhesion proteins and cell adhesion proteins, with genetic susceptibility, are associated with the development of vasculopathy [17].

An assessment of the endothelium can be made by an analysis of the various markers reflecting the vascular endothelium functions at different levels of its activity, comprising measurement of factors such as VCAM-1, ICAM-1, fibrinogen, thrombomodulin, interleukin, and the von Willebrand factor. These markers indirectly or directly reflect the degree of endothelial damage or dysfunction [10, 18, 19]. The state of the endothelium is considered to be an integrated indicator of all the factors affecting coronary vasculopathy development. Thus, the markers that reflect activation of different components of the endothelium can be valuable markers used to detect and monitor the progress of CAV [14].

\section{Systemic inflammatory response}

Chronic inflammation is recognized as one of the main features of atherosclerosis development. In the past few years, numerous studies have indicated that systemic inflammation may also accompany CAV $[20,21]$. Chronic inflammation is a result of the release of pro-inflammatory cytokines and chronic activation of the immune system. The biochemical exponent of the inflammatory process is an increased number of neutrophil granulocytes, C-reactive protein, fibrinogen, adhesion molecules (ICAM-1 and VCAM-1), and pro-inflammatory cytokines. On the other hand, circulating cytokines may impair the functioning of the endothelium, either directly or indirectly, through the impact on the level of factors such as high-sensitivity C-reactive protein (hs-CRP) and fibrinogen [14, 22, 23].

One of the most sensitive markers of systemic inflammation is the C-reactive protein. C-reactive protein is produced in the liver and it reflects the total cytokine activity in the body [20]. Research shows that increased levels of hs-CRP can be used as an indicator of increased vasculopathy risk [21, 22]. Other studies also confirm the role of hs-CRP as a sensitive marker of the risk for vasculopathy development and a medium constituting the composite endpoint of cardiovascular events and death in patients after transplanta- 
tion [21]. Furthermore, Pethig et al. reported that the level of hs-CRP correlates with the rate of progression of vasculopathic changes [20], and a high level is associated with higher graft losses [21]. C-reactive protein is also associated with increased expression of ICAM-1 and VCAM-1 on endothelial cells. In turn, these molecules play a significant role in attracting the cells to the site of atherosclerotic plaque formation [23]. Labarrere et al. reported that increased expression of ICAM-1 levels in plasma, accompanying the increase of CRP, is a prognostic factor of an aggressive and rapidly progressive CAV [24]. Significantly higher levels of CRP, fibrinogen, ICAM-1 and VCAM-1 adhesion molecules and an increased number of leukocytes have been noted in patients with cardiac allograft vasculopathy with a considerable degree of coronary lesions, compared to those with CAV with minor changes in the vessels. Given the effect of the increased inflammation on CAV development, proven in numerous clinical studies, future clinical trials should be directed at the inhibition of inflammation, particularly in the postoperative period. In addition, patients with high hsCRP levels should be carefully monitored.

\section{Classic cardiovascular risk factors for cardiac allograft vasculopathy development}

Important groups of risk factors for CAV development are modifiable and non-modifiable classic cardiovascular factors. Modifiable factors include dyslipidemia, diabetes mellitus, hypertension, obesity, markers of chronic inflammation, metabolic syndrome and prothrombotic factors. Non-modifiable factors include age, gender and genetic markers. In addition, a separate and a very important group consists of lifestyle factors: diet, smoking and physical activity [8, 15, 25].

Risk factors for cardiovascular diseases are closely related to the development of classical coronary atherosclerosis. There has been more and more conclusive evidence that the classical cardiovascular factors also affect CAV development, as well as the progression of vascular lesions of the transplanted heart [8]. Many cardiovascular risk factors, including diabetes, obesity, dyslipidemia, and hypertension, are often more prevalent in a population of patients after heart transplantation, as compared with the general population [9]. This group of patients should be subjected to careful observation.

Sánchez Lázaro et al. studied the impact of cardiovascular risk factors in heart transplant recipients on CAV occurrence in a one-year follow-up. In this study dyslipidemia and ischemia were significantly associated with CAV development. In the case of factors such as older age, hypertension, smoking and obesity, only a tendency towards frequent CAV occurrence was observed in the analyzed group of patients [8]. In the population of patients after heart transplantation the classic risk factors, especially hypertension, dyslipidemia, smoking and diabetes, often accumulate, and therefore the resultant of all these factors contributes to faster progression of coronary lesions. On the other hand, other studies also show that older age, male gender, higher weight and blood type $\mathrm{O}$ occurring in the donor are associated with an increased CAV risk in heart transplant recipients. The cumulative risk of CAV development increases from $22 \%$ after 5 years to $39 \%$ after 10 years [5]. A higher weight of the donor may be associated with a higher probability of the presence of atherosclerosis "transferred" together with the heart from the donor to the recipient, and it also forms the basis for CAV. Importantly, the research shows that donor age above 32 is already associated with an increased CAV risk in the recipient [5]. Heart transplant patients are at risk for a number of atherogenic factors that may significantly contribute to CAV development. Particularly important is the presence of an increased ratio of total cholesterol/high-density lipoprotein (HDL), increased level of triglycerides, lipoprotein a, homocysteine, fibrinogen and reduced HDL level [26]. Many of these factors are present in patients with cardiac allograft vasculopathy. The role of lipid disorders in CAV progression is also confirmed by its lesser severity or regression in patients taking cholesterol-lowering drugs $[1,26]$.

Disorders of carbohydrate metabolism may adversely affect the coronary arteries by several mechanisms. Diabetes mellitus is common in heart transplant recipients and occurs in $28 \%$ of them within one year after transplantation, and in $40 \%$ of patients within five years after the surgery [1]. Diabetes manifesting itself in the early post-transplant period may also play a role in the development of the acute rejection process. Numerous episodes of acute rejection are in turn a factor contributing to the development of vasculopathy. Metabolic disorders developing in diabetes are also associated with impaired endothelial functions, inducing generalized inflammation, and disorders in the balance of the coagulation system processes closely related to CAV [27-29]. In contrast, another study reported that diabetes induced after transplantation does not affect the incidence of CAV [30]. Similar observations regarding the lack of the impact of type 2 diabetes on CAV development were made by Zakliczyński et al. [31]. Due to ambiguous data on the impact of diabetes on the development of vasculopathy, there is a need for further studies that will define the role of diabetes in CAV development.

Markers of insulin resistance, defined as TG/HDL ratio $\geq 3$, and CRP level in excess of $3 \mathrm{mg} / \mathrm{l}$ of insulin can also lead to endothelial dysfunction and CAV development [1, 31]. The significant correlation between markers of insulin resistance and systemic inflammation suggests a pathophysiological link between immuno-inflammatory activation and insulin resistance.

Many risk factors for cardiovascular disease are common among heart transplant recipients. In order to prevent or slow the progression of vasculopathic changes, an intensive treatment aimed at the modification of these factors should be taken into consideration.

\section{The effect of Cytomegalovirus and hepatitis C virus infections on the development of cardiac allograft vasculopathy}

Cytomegalovirus is one of the most common viral pathogens isolated in patients after heart transplantation. 
With the start of immunosuppressive treatment, the rate of the infection with this virus is significantly increased, due to the blocking of the most important step of the antiviral defense, which is a cytotoxic $T$ lymphocyte response dependent on HLA, by immunosuppressive drugs. In the first months after transplantation, CMV infection occurs in 6090\% of the transplant recipients [7].

Data show that the frequent CMV infections in patients after heart transplantation affect the rate of accelerated coronary atherosclerosis development [7, 32]. The presence of the adenoviral genome in heart transplant recipients increases the risk of CAV development six-fold, suggesting the role of viral infection in the progression of changes in the coronary arteries of the graft [32]. Cytomegalovirus modulates the immune system and leads to stimulation of the inflammatory process with a simultaneous release of cytokines. The occurrence of coronary vasculopathy in patients after heart transplantation may now be explained on the immunological basis, which is stimulated by CMV $[7,32]$. In the recipients diagnosed with CMV infection, the presence of autoantibodies of different specificity occurs. There is a close correlation between high levels of these antibodies and changes within the coronary endothelium of the transplanted heart. An excessive humoral response in relation to endothelial cells carries a significant risk of adverse changes within the vascular graft and consequently lower graft survival [7, 32]. Cytomegalovirus can directly damage endothelial cells as well as acting indirectly by stimulating the immune system, including the release of pro-inflammatory cytokines, and an increase of the expression of soluble forms of adhesion molecules (ICAM-1, VCAM-1, selectins) and chemokines [13, 33]. Significant concentric intimal proliferation and scattered atherosclerotic lesions, which lead to lumen narrowing in patients with asymptomatic or symptomatic cytomegalovirus infection, have been observed in various studies [32, 33]. Early detection of subclinical CMV infection in transplant patients may lead to the limitation of incidence of acute rejection episodes and help to reduce the progression rate of the vasculopathic changes within the graft [7].

Many studies have analyzed the effect of CMV infections on the development of cardiac graft vasculopathy, while only a few have focused on the effects of the infection with hepatitis $\mathrm{C}$ virus ( $\mathrm{HCV}$ ) on the incidence and the progression rate of changes in coronary vessels of the graft. The frequency of HCV infection among heart transplant recipients is about $7-18 \%$ [34]. The infection transmission may occur through blood transfusions and with the heart of a HCV-positive donor. However, the exact mechanisms of HCV transmission from seropositive donors to heart transplant recipients are not fully understood. It appears that HCV seropositivity of the donor can be one of the factors influencing the graft survival and CAV development [34, 35]. Haji et al. have reported that a donor HCV infection is an independent risk factor for accelerated coronary artery disease development after heart transplantation. The CAV risk in an observation period of $3.4 \pm 1.6$ years was 3 -fold higher in patients with HCV-positive donors, as compared to the control group, in which both the donor and recipient were not infected with HCV. The mechanism of this phenomenon has not been identified [35]. Other studies also confirm that the heart transplanted from a seropositive donor is the cause of worse graft survival, regardless of the condition and age of the recipient [34]. There is a need to investigate this matter further, due to the scarce data on the impact of HCV seropositivity of the donor on CAV development.

\section{$\boldsymbol{N}$-terminal propeptide B-type natriuretic peptide as a vasculopathy indicator}

$N$-terminal propeptide B-type natriuretic peptide (NT-proBNP) is a marker of cardiac volume overload, and its synthesis and secretion are the result of complex and interrelated neuroendocrine and immunological mechanisms.

The evaluation of NT-proBNP is useful in the diagnosis of heart failure, but more and more studies have been showing that high levels of this indicator correlate with the rate of vasculopathy development after heart transplantation $[36,37]$. Studies by Mehra et al. indicate that BNP is closely related to CAV development and may also serve as a marker for the probability of sudden cardiac death [36]. The increase in BNP level after heart transplantation can reflect the direct impact of metabolic factors, which include diabetes, hypertension and lipid disorders, on the development of coronary vasculopathy $[5,36]$. The close connection between the development of vasculopathy with an increased NT-proBNP level in patients after heart transplantation has also been confirmed by Ambrosi et al. [37]. It is suggested that the levels of BNP and pro-BNP are associated with graft rejection, left ventricular hypertrophy, a history of immunosuppressive therapy, renal failure, and increased levels of endothelin, and thus the factors which affect the progression rate of CAV $[37,38]$. Therefore, NT-pro-BNP level may be a useful predictor of CAV development and a prognostic factor for survival of the graft $[36,37]$.

\section{The role of uric acid in cardiac allograft vasculopathy development}

Uric acid is the final metabolite of purine metabolism, and an increased level of it may be the result of overproduction or reduction of the renal excretion. Uric acid stimulates the synthesis of monocyte chemoattractant protein (MCP-1), interleukin-1 $\beta$, interleukin-6 and tumor necrosis factor $\alpha$ (TNF- $\alpha$ ). It should be pointed out that many of these factors are associated with CAV development [39-41].

Arora et al. evaluated the relationship between uric acid in the serum and CAV development and mortality within one year following heart transplantation. The authors reported that an increased level of uric acid in serum is an important risk factor for the development of moderate to severe CAV. Additionally, a high level of uric acid is associated with the presence of a significantly higher concentration of hs-CRP and NT-pro-BNP [39]. The association between high levels of uric acid and high CRP concentration shows 
the relationship between uric acid and inflammation [41]. Other researchers have also confirmed that an increased level of uric acid is a predictive factor for the development of CAV [40]. However, no studies have determined the exact relationship between uric acid and the progression rate of CAV in long-term follow-up. In the future these studies may have clinical relevance regarding the use of xanthine oxidase inhibitors in transplant recipients in order to inhibit the development of CAV.

\section{Conclusions}

Cardiac allograft vasculopathy is one of the major causes of late failure after heart transplantation. The complex pathophysiology of the disorder and the strong influence of immunological and non-immunological factors on the progression of vasculopathy greatly hinder effective treatment of the already developed changes. Therefore, the treatment strategy of patients after heart transplant should be based on CAV prevention, through modification of the risk factors. Early diagnosis of the disease, by monitoring the level of risk factors strongly associated with CAV development, may prove to be a key element in preventing or slowing progression of the disease. Particularly, patients with multiple risk factors for CAV development should undergo a thorough analysis and be carefully monitored.

\section{Disclosure}

Authors report no conflict of interest.

\section{References}

1. Vecchiati A, Tellatin S, Angelini A, Iliceto S, Tona F. Coronary microvasculopathy in heart transplantation: Consequences and therapeutic implications. World J Transplant 2014; 4: 93-101.

2. Lund LH, Edwards LB, Kucheryavaya AY, Dipchand Al, Benden C, Christie JD, Dobbels F, Kirk R, Rahmel AO, Yusen RD, Stehlik J. Registry of the International Society for Heart and Lung Transplantation: Thirtieth Official Adult Heart Transplant Report - 2013; focus theme: age. J Heart Lung Transplant 2013; 32: 951-964.

3. Gao SZ, Hunt SA, Schroeder JS, Alderman E, Hill IR, Stinson EB. Does rapidity of development of transplant coronary artery disease portend a worse prognosis? J Heart Lung Transplant 1994; 13: 1119-1124.

4. Braga JR, Santos IS, McDonald M, Shah PS, Ross HJ. Factors associated with the development of cardiac allograft vasculopathy - a systematic review of observational studies. Clin Transplant 2012; 26: E111-E124.

5. Caforio AL, Tona F, Fortina AB, Angelini A, Piaserico S, Gambino A, Feltrin G, Ramondo A, Valente M, Iliceto S, Thiene G, Gerosa G. Immune and nonimmune predictors of cardiac allograft vasculopathy onset and severity: multivariate risk factor analysis and role of immunosuppression. Am J Transplant 2004; 4: 962-970.

6. Roig E, Almenar L, Crespo-Leiro M, Segovia J, Mirabet S, Delgado J, PérezVilla F, Luís Lambert J, Teresa Blasco M, Muńiz J. Heart transplantation using allografts from older donors: Multicenter study results. J Heart Lung Transplant 2015; 34: 790-796.

7. Delgado JF, Reyne AG, de Dios S, López-Medrano F, Jurado A, Juan RS, RuizCano MJ, Dolores Folgueira M, Gómez-Sánchez MÁ, Aguado JM, Lumbreras $C$. Influence of cytomegalovirus infection in the development of cardiac allograft vasculopathy after heart transplantation. J Heart Lung Transplant 2015; 34: 1112-1119.

8. Sánchez Lázaro IJ, Almenar Bonet L, Moro López J, Sánchez Lacuesta E, Martínez-Dolz L, Agüero Ramón-Llín J, Andrés Lalaguna L, Cano Pérez O, Ortiz Martínez V, Buendía Fuentes F, Salvador Sanz A. Influence of traditional cardiovascular risk factors in the recipient on the development of cardiac allograft vasculopathy after heart transplantation. Transplant Proc 2008; 40: 3056-3057.
9. Valantine H. Cardiac allograft vasculopathy after heart transplantation: risk factors and management. J Heart Lung Transplant 2004; 23: S187-S193.

10. Reinhart K, Bayer O, Brunkhorst F, Meisner M. Markers of endothelial damage in organ dysfunction and sepsis. Crit Care Med 2002; 30: S302-S312.

11. Mehra MR, Crespo-Leiro MG, Dipchand A, Ensminger SM, Hiemann NE, Kobashigawa JA, Madsen J, Parameshwar J, Starling RC, Uber PA. International Society for Heart and Lung Transplantation working formulation of a standardized nomenclature for cardiac allograft vasculopathy - 2010. J Heart Lung Transplant 2010; 29: 717-727.

12. Valenzuela NM, Reed EF. Antibodies in transplantation: the effects of HLA and non-HLA antibody binding and mechanisms of injury. Methods Mol Biol 2013; 1034: 41-70.

13. Belperio JA, Ardehali A. Chemokines and transplant vasculopathy. Circ Res 2008; 103: 454-466.

14. Gotlieb A. Systemic and nontraditional markers of endothelial dysfunction. Can J Cardiol 2000; 16: 27E-31E.

15. Conroy RM, Pyörälä K, Fitzgerald AP, Sans S, Menotti A, De Backer G, De Bacquer D, Ducimetière P, Jousilahti P, Keil U, Njølstad I, Oganov RG, Thomsen T, Tunstall-Pedoe H, Tverdal A, Wedel H, Whincup P, Wilhelmsen L, Graham IM. Estimation of ten-year risk of fatal cardiovascular disease in Europe: the SCORE project. Eur Heart J 2003; 24: 987-1003.

16. Ruf A, Patscheke H. Flow cytometric detection of activated platelets: comparison of determining shape change, fibrinogen binding, and P-selectin expression. Semin Thromb Hemost 1995; 21: 146-151.

17. He JQ, Gaur LK, Stempien-Otero A, Nelson K, Levy WC, O’Brien KD, Bolgiano DC, Reiner AP. Genetic variants of the hemostatic system and development of transplant coronary artery disease. J Heart Lung Transplant 2002; 21: 629-636.

18. Lip GY, Blann AD, Farooqi IS, Zarifis J, Sagar G, Beevers DG. Sequential alterations in haemorheology, endothelial dysfunction, platelet activation and thrombogenesis in relation to prognosis following acute stroke: The West Birmingham Stroke Project. Blood Coagul Fibrinolysis 2002; 13: 339-347.

19. Labarrere CA, Nelson DR, Miller SJ, Nieto JM, Conner JA, Pitts DE, Kirlin PC, Halbrook HG. Value of serum-soluble intercellular adhesion molecule-1 for the noninvasive risk assessment of transplant coronary artery disease, posttransplant ischemic events, and cardiac graft failure. Circulation 2000; 102: 1549-1555.

20. Pethig K, Heublein B, Kutschka I, Haverich A. Systemic inflammatory response in cardiac allograft vasculopathy: high-sensitive C-reactive protein is associated with progressive luminal obstruction. Circulation 2000; 102: III233-III236.

21. Raichlin ER, McConnell JP, Lerman A, Kremers WK, Edwards BS, Kushwaha SS, Clavell AL, Rodeheffer RJ, Frantz RP. Systemic inflammation and metabolic syndrome in cardiac allograft vasculopathy. J Heart Lung Transplant 2007; 26: 826-833.

22. Hognestad A, Endresen K, Wergeland R, Stokke O, Geiran O, Holm T, Simonsen S, Kjekshus JK, Andreassen AK. Plasma C-reactive protein as a marker of cardiac allograft vasculopathy in heart transplant recipients. J Am Coll Cardiol 2003; 42: 477-482.

23. Pasceri V, Willerson JT, Yeh ET. Direct proinflammatory effect of C-reactive protein on human endothelial cells. Circulation 2000; 102: 2165-2168.

24. Labarrere CA, Lee JB, Nelson DR, Al-Hassani M, Miller SJ, Pitts DE. C-reactive protein, arterial endothelial activation, and development of transplant coronary artery disease: a prospective study. Lancet 2002; 360: 1462-1467.

25. Wilson PW, D’Agostino RB, Levy D, Belanger AM, Silbershatz H, Kannel WB. Prediction of coronary heart disease using risk factor categories. Circulation 1998; 97: 1837-18447.

26. Cooke GE, Eaton GM, Whitby G, Kennedy RA, Binkley PF, Moeschberger ML, Leier CV. Plasma atherogenic markers in congestive heart failure and posttransplant (heart) patients. J Am Coll Cardiol 2000; 36: 509-516.

27. Wilkinson A, Davidson J, Dotta F, Home PD, Keown P, Kiberd B, Jardine A, Levitt N, Marchetti P, Markell M, Naicker S, O'Connell P, Schnitzler M, Standl E, Torregosa JV, Uchida K, Valantine H, Villamil F, Vincenti F, Wissing M. Guidelines for the treatment and management of new-onset diabetes after transplantation. Clin Transplant 2005; 19: 291-298.

28. van den Oever IA, Raterman HG, Nurmohamed MT, Simsek S. Endothelial Dysfunction, Inflammation, and Apoptosis in Diabetes Mellitus. Mediators Inflamm 2010; 2010: 792393.

29. Mogollón Jiménez MV, Sobrino Márquez JM, Arizón Muńoz JM, Sánchez Brotons JA, Guisado Rasco A, Hernández Jiménez MM, Romero Rodríguez N, Borrego Domínguez JM, Ordońez Fernández A, Lage Gallé E, Martínez Mar- 
tínez A. Incidence and Importance of De Novo Diabetes Mellitus After Heart Transplantation. Transplant Proc 2008; 40: 3053-3055.

30. Klingenberg R, Gleissner C, Koch A, Schnabel PA, Sack FU, Zimmermann R, Katus HA, Dengler TJ. Impact of pre-operative diabetes mellitus upon early and late survival after heart transplantation: a possible era effect. J Heart Lung Transplant 2005; 24: 1239-1246.

31. Zakliczynski M, Nozynski J, Konecka-Mrowka D, Pyka L, Trybunia D, Nikiel B, Mlynarczyk-Liszka J, Lange D, Zembala M. Different role of advanced glycation end products in pathology of transplanted heart in patients with or without diabetes mellitus type 2. Transplant Proc 2009; 41: 3185-3189.

32. Valantine HA. The role of viruses in cardiac allograft vasculopathy. Am J Transplant 2004; 4: 169-177.

33. Potena L, Valantine HA. Cytomegalovirus-associated allograft rejection in heart transplant patients. Curr Opin Infect Dis 2007; 20: 425-431.

34. Fong TL, Hou L, Hutchinson IV, Cicciarelli JC, Cho YW. Impact of hepatitis C infection on outcomes after heart transplantation. Transplantation 2009; 88: 1137-1141.

35. Haji SA, Starling RC, Avery RK, Mawhorter S, Tuzcu EM, Schoenhagen P, Cook DJ, Ratliff NB, McCarthy PM, Young JB, Yamani MH. Donor hepatitis-C seropositivity is an independent risk factor for the development of accelerated coronary vasculopathy and predicts outcome after cardiac transplantation. J Heart Lung Transplant 2004; 23: 277-283.
36. Mehra MR, Uber PA, Potluri S, Ventura HO, Scott RL, Park MH. Usefulness of an elevated B-type natriuretic peptide to predict allograft failure, cardiac allograft vasculopathy, and survival after heart transplantation. Am J Cardiol 2004; 94: 454-458.

37. Ambrosi P, Oddoze C, Ribéri A, Arques S, Portugal H, Métras D, Habib G. Usefulness of $\mathrm{N}$-terminal-pro-brain natriuretic peptide levels in predicting survival in heart transplant recipients. Am J Cardiol 2004; 94: 1585-1587.

38. Shaw SM, Fildes J, Yonan N, Williams SG. Does brain natriuretic peptide interact with the immune system after cardiac transplantation? Transplantation 2007; 84: 1377-1381.

39. Arora S, Aukrust P, Ueland T, Broch K, Simonsen S, Gude E, Fiane AE, Geiran O, Wergeland R, Andreassen AK, Gullestad L. Elevated serum uric acid levels following heart transplantation predict all-cause and cardiac mortality. Eur J Heart Fail 2009; 11: 1005-1013.

40. Kittleson MM, Bead V, Fradley M, St John ME, Champion HC, Kasper EK, Russell SD, Wittstein IS, Hare JM. Elevated uric acid levels predict allograft vasculopathy in cardiac transplant recipients. J Heart Lung Transplant 2007; 26: 498-503.

41. Kang DH, Park SK, Lee IK, Johnson RJ. Uric acid induced C-reactive protein (CRP) expression: Implication on cell proliferation and nitric oxide production in human vascular cells. J Am Soc Nephrol 2005; 16: 3553-3562. 